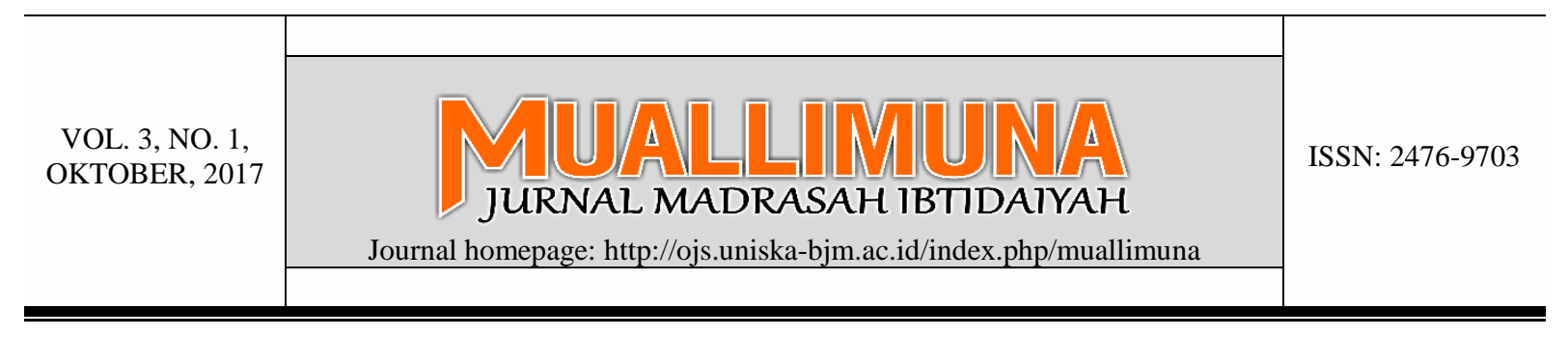

\title{
Pengembangan Media Pembelajaran Matematika berbasis Android untuk Siswa SD/MI
}

\section{INFORMASI ARTIKEL}

Penulis:

Hamdan Husein Batubara

Dosen Prodi Penddikan Guru

Madrasah Ibtidaiyah,

Universitas Islam Kalimantan

MAB Banjarmasin, Indonesia

Email:

huseinbatubara@gmail.com

\section{Kata Kunci:}

Media Pembelajaran

Android,

Matematika,

$\mathrm{SD} / \mathrm{MI}$

Halaman: 12-27

\section{A B S T R AK}

\section{Indonesia}

Pendahuluan: Penelitian ini bertujuan untuk menghasilkan media pembelajaran matematika berbasis android untuk siswa SD/MI dengan melibatkan pakar pada proses pengembangan dan penilaian produknya. Metode: Penelitian ini merupakan penelitian pengembangan (Research and Development). Prosedur pengembangan menggunakan model 4D, yaitu: define (analisis pengguna, kurikulum, dan bahan ajar), design (merancang produk dengan alat dan bahan), develop (penilaian dan revisi), dan disseminate (uji coba pada calon pengguna). Instrumen penelitian ini adalah angket. Tim penilai produk terdiri: ahli, peer reviewer, guru SD/MI, dan respon siswa kelas IV SD/MI. Hasil: 1) Peneliti telah menghasilkan media pembelajaran matematika berbasis android pada materi bangun datar untuk siswa kelas IV SD/MI, 2) Penilaian ahli, peer reviewer dan guru sekolah dasar terhadap produk mendapat skor 434 dan persentase 86,67\%, sangat baik, 3) tanggapan siswa kelas IV SD/ MI terhadap media pembelajaran matematika berbasis android memperoleh skor 439 dengan persentase penilaian 87,8\%. Nilai tersebut berada pada interval antara setuju dan sangat setuju.

\section{English}

Introduction: This study aims to produce a learning media of mathematics based on Android for Elementary School students by involving Experts in the process of development and assessment. Method: This research is a research development. Procedures of development using the $4 \mathrm{D}$ model. namely: define (analysis of user, curriculum, and 


\section{PENDAHULUAN}

Sekolah Dasar/ Madrasah Ibtidaiyah merupakan jenjang awal untuk menanamkan konsep dasar bagi anak, sehingga konsep-konsep yang diterima anak sebagai pembuka daya pikirnya dalam menghadapi jenjang berikutnya. Sesuai dengan sifat materi pelajaran matematika bersifat abstrak, maka pembelajaran matematika harus sesuai dengan tingkat perkembangan diri anak (Waskito, 2014). Dalam hal ini, guru sebagai ujung tombak atau direktur pendidikan bertugas menyiapkan lingkungan dan fasilitas belajar yang menarik dan mendukung perkembangan potensi dan akhlak peserta didik.
Pembelajaran matematika sebagai salah satu mata pelajaran MI/SD memiliki peran penting dalam memenuhi kebutuhan hidup siswa. Tujuan pembelajaran matematika di sekolah menurut Permendiknas No. 22 tahun 2006 meliputi hal berikut: 1) Memahami konsep matematika, menjelaskan keterkaitan antar konsep dan mengaplikasikan konsep atau algoritma secara luas, akurat, efisien, dan tepat dalam pemecahan masalah; 2) Menggunakan pemahaman pada pola dan sifat, melakukan manipulasi matematika dalam membuat generalisasi, menyusun bukti, atau menjelaskan gagasan dan pernyataan matematika; 3) memecahkan masalah yang meliputi kemampuan 
memahami masalah, merancang model matematika, menyelesaikan model dan menafsirkan solusi yang diperoleh; 4) Mengkomunikasikan gagasan dengan simbol, tabel, diagram, atau media lain untuk memperjelas keadaan atau masalah; 5) Memiliki sikap menghargai kegunaan matematika dalam kehidupan, yaitu memiliki rasa ingin tahu, perhatian dan minat dalam mempelajari matematika, serta sikap ulet dan percaya diri dalam pemecahan masalah (Lidinillah, 2008).

Berdasarkan tujuan diatas, pemahaman konsep dan komunikasi matematis merupakan kompetensi yang harus dikembangkan dalam diri siswa agar mereka siap menghadapi permasalahan hidup di masa mendatang. Selain itu, kompetensi afektif, seperti semangat belajar, kemandirian dan ketekunan juga merupakan modal penting bagi siswa dalam mengembangkan potensinya secara maksimal.

Salah satu materi pelajaran matematika yang dekat dengan kehidupan siswa adalah materi geometri, yaitu salah satu cabang matematika yang mempelajari titik, garis, bidang dan benda-benda ruang serta sifat-sifatnya, ukuran-ukurannya dan hubungannya satu sama lain. Contoh penerapan materi ini dalam kehidupan sehari-hari antara lain: sudut digunakan untuk mengukur suatu gedung, diameter lingkaran digunakan untuk membuat roda agar seimbang, bidang setengah bola digunakan untuk membuat jembatan, segitiga sama kaki digunakan untuk membuat atap rumah, bidang datar sebagai dasar pembuatan lantai, dan persegi panjang digunakan untuk membuat sejadah.

Kenyataan di lapangan menunjukkan bahwa materi geometri kurang dikuasai oleh sebagian besar siswa. Herawati dalam kutipan Nur'aeni melaporkan bahwa hasil penelitiannya menemukan bahwa masih banyak siswa sekolah dasar yang belum memahami konsep-konsep dasar geometri, di antaranya dalam pe- mahaman konsep geometri datar. Menurut hasil penelitian Nur'aeni, hampir 95\% siswa SD kelas V beranggapan bahwa segi empat itu adalah persegi dan segi tiga itu adalah segitiga sikusiku (Nur'aeni, 2010). Temuan Nue'aeni tersebut juga masih menjadi masalah yang peneliti jumpai saat melakukan studi pendahuluan, misalnya: siswa sering tertukar dalam menyebutkan nama bangun datar dan salah dalam menggunakan rumus bangun datar. 
Syaiful Bahri Djamarah dalam kutipan Batubara mengungkapkan bahwa salah satu faktor yang sangat penting dalam mempengaruhi proses belajar siswa di SD/MI adalah kehadiran media pembelajaran. Kehadiran media pembelajaran sangat membantu siswa yang sedang dalam fase operasinal konkret dalam memahami materi yang bersifat abstrak atau kurang mampu dijelaskan dengan bahasa verbal. Kerumitan bahan yang akan disampaikan pada anak didik juga dapat disederhanakan dengan bantuan media pembelajaran sehingga peserta didik dapat lebih cepat dalam memahami materi pelajaran (Batubara, 2015).

Salah satu jenis media pembelajaran yang dinilai memiliki pengaruh positif pendidikan adalah media yang menggunakan perangkat TIK. bersifat abstrak dan rumit. Selain itu, pemanfaatan TIK juga menggeser paradigma tentang belajar, yaitu: 1) Peran guru sebagai sumber informasi ke fasilitator pembelajaran, 2) Ruang kelas ke dimana dan kapan saja dapat dilaksanakan kegiatan pembelajaran, 3) kertas ke bahan digital yang online atau daring, 4) fasilitas fisik ke fasilitas jaringan, dan 5) dari waktu siklus (terjadwal) ke waktu nyata.
Besarnya peran dan fungsi TIK bagi pembelajaran mengharuskan guru mampu memanfaatkan TIK untuk kegiatan pembelajaran. Kemampuan ini sangat penting bagi peningkatan kompetensi pedagogik dan profesional guru. Pemerintah juga telah memfasilitasi bahan ajar berbasis TIK guna mendukung penerapan pembelajaran berbasis TIK di sekolah, Seperti rumah belajar, TV Edukasi, radio pendidikan, dan mobile edukasi (Menteri Pendidikan Nasional RI, 2007).

Beberapa aspek yang harus dikuasi guru terkait dengan TIK adalah: 1) peraturan penggunaan TIK, 2) penggunaan TIK dalam pengembangan kurikulum dan penilaian, 3) penggunaan TIK pada pedagogi, 4) penguasaan peralatan dan bahan-bahan TIK, 5) etika penggunaan TIK dalam manajemen organisasi dan administrasi, dan 6) penggunaan TIK dalam meningkatkan profesionalisme guru. Adapun tingkatan kompetensi guru dalam menggunakan TIK terdiri dari tiga tingkat, yaitu: 1) menguasai dasar-dasar TIK (Technology Literacy), 2) mendalami dan merekayasa pengetahuannya melalui TIK (Knowledge Deepening),dan 3) mempunyai kemampuan untuk mengkreasi pengetahuan dengan TIK (Knowledge Creation) (UNESCO, 2011). 
Meskipun penggunaan TIK secara teratur dan terancana telah diyakini mampu meningkatkan kualitas pembelajaran, namun penggunaan TIK di sekolah masih menghadapi berbagai persoalan. Persoalan tersebut ada yang berasal dari dalam diri guru (internal) dan dari luar diri guru (eksternal). Contoh masalah internal adalah: sikap guru dalam menerima perubahan, tingkat penguasaan guru terhadap penggunaan perangkat TIK, kemampuan guru dalam mebuat media pembelajaran berbasis TIK, persepsi guru terhadap peran dan fungsi TIK di Sekolah, inisiatif guru untuk belajar mandiri dan berkolaborasi, dan rasa percaya diri guru dalam menghadapi berbagai tantangan atau masalah. Sementara contoh masalah eksternal adalah dukungan infrastruktur, regulasi tentang penggunaan TIK, dan kebijakan kepala sekolah/ dinas pendidikan. Dalam rangka mendukung penggunaan TIK di kelas/ sekolah maka perlu dilakukan tiga hal, yaitu: 1) siswa dan guru harus memiliki akses teknologi digital dan internet dalam kelas, sekolah, dan lembaga pendidikan guru, 2) harus tersedia materi yang berkualitas, bermakna, dan dukungan kultural bagi siswa dan guru, dan 3) guru harus memiliki pengetahuan dan keterampilan menggunakan alat-alat dan sumber-sumber digital untuk membantu siswa mencapai standar akademik.

Penelitian dan pengembangan ini adalah salah satu upaya memproduksi sebuah media pembelajaran matematika berbasis android yang dapat digunakan siswa secara mandiri di rumahnya sebagai pendukung pembelajaran di kelas. Produk tersebut diproduksi melalui kegiatan penelitian bertujuan untuk memastikan bahwa media yang dihasilkan telah memenuhi syarat-syarat yang ditetapkan. Oleh karena itu, fokus masalah penelitian ini adalah: Bagaimana bentuk media pembelajaran matematika berbasis Android pada MI/SD yang yang layak digunakan di SD berdasarkan penilaian ahli media atau reviewer dan siswa MI/SD.

\section{METODE}

Penelitian dan pengembangan (research and development) sebagai jenis penelitian ini bertujuan untuk menghasilkan produk baru melalui proses pengembangan yang terintegrasi dengan kegiatan penelitian. Jenis penelitian yang terintegrasi dalam pengembangan produk ini adalah survei tentang pendapat pakjar dan respon pengguna terhadap produk yang dikembangkan. Pengembangan media 
pembelajaran berbasis Android ini menggunakan model 4D, yaitu: define (analisis karakteristik pengguna, kurikulum, dan bahan ajar), design (merancang produk dengan alat dan bahan), develop (penilaian dan revisi), dan disseminate (uji coba pada calon pengguna) (Mulyatiningsih, 2014).

Instrumen yang digunakan untuk mengumpulkan data kualitas produk adalah: Pertama, Lembar angket berbentuk check listy untuk mendapatkan penilaian dari pakar yang meliputi peer reviewer dan guru. Aspek kriteria penilaian media pembelajaran berbasis Android yang digunakan dalam penelitian ini adalah: 1) aspek penyajian materi, 2) aspek kurikulum, 3) aspek kegiatan atau percobaan, 4) aspek evaluasi belajar, 5) aspek keterlaksanaan, 6) aspek kualitas tampilan, 7) aspek kebahasaan, dan 8) aspek kejelasan kalimat.

Kedua, Lembar angket berbentuk check list yang digunakan untuk mendapatkan data respon siswa. Aspek kriteria respon siswa yang dikumpulkan dalam penelitian ini adalah: 1) Kemudahan pemahaman terhadap pelajaran, 2) Kemandirian belajar, 3) Minat terhadap media pembelajaran berbasis Android, 4) Kemanfaatan media, dan 5) Kemudahan dalam penggunaan.
Ketiga, Dokumentasi dari berbagai dokumen yang diperlukan dalam penelitian ini, seperti: ruang lingkup materi geometri di MI/SD, Data guru dan siswa yang akan dilibatkan dalam penelitian ini.

Teknik analisis data uji kualitas produk bertujuan untuk mengetahui kualitas media pembelajaran menggunakan media pembelajaran berbasis android berdasarkan tanggapan ahli materi dan ahli media dan kelompok reviewer yang terdiri dari teman sejawat (peer-reviewer) yaitu 3 orang dosen dan 2 orang guru MI/SD. Setelah itu, dilakukan juga teknik analisis data uji coba terbatas kepada siswa MI/SD yang bertujuan untuk mengetahui efektifitas media pembelajaran berbasis android berdasarkan respon mereka. Respon siswa MI/SD terhadap media pembelajaran berbasis Android dianalisis dengan analisis deskriptif.

\section{HASIL DAN PEMBAHASAN}

Berdasarkan desain penelitian dan pengembangan yang sudah dikemukakan, maka pengembangan media pembelajaran berbasis Android ini dilakukan dalam empat tahapan pengembangan (model 4D), yaitu: 


\section{a. Analisis Karakteristik Pengguna,} Kurikulum, dan Bahan Ajar (Define)

Sasaran analisis yang dilakukan adalah karakteristik peserta didik, perangkat dan bahan ajar yang tersedia, dan skill tenaga pengajar. Adapun hasil yang ditemukan di lapangan adalah:

1) Sebagian siswa kurang berminat dalam belajar matematika ini hal ini dikarenakan siswa berpikiran bahwa matematika itu adalah pelajaran yang sulit.

2) Hampir semua siswa bisa menggunakan perangkat Smarphone Android untuk bermain game dan menonton video

3) Siswa sering menghabiskan waktunya bermain Smartphone Android

4) Media pembelajaran matematika berbasis Android yang sesuai dengan kurikulum 2013 masih sulit ditemukan di sekolah

5) Belum banyak guru yang memiliki kemampuan dalam membuat media pembelajaran matematika berbasis Android

6) Salah satu materi pelajaran matematika yang cocok diajarkan menggunakan media pembelajaran Android adalah materi bangun datar di kelas 4. Hal tersebut dikarenakan materi ini melibatkan banyak objek visual terkait karakteristik dan teknik mengukur bangun datar (Sembiring, 2017).

\section{b. Merancang Produk dengan Alat dan Bahan (Design)}

Dalam mendesain produk media pembelajaran matematika berbasis android dilakukan beberapa tahapan, yaitu: a) Memetakan kompetensi dasar dan tujuan pembelajaran, b) Menentukan alat penilaian, c) Menyusun bangunan materi, dan d) mendesain model alur berpikir program media pembelajaran atau dikenal dengan istilah flowchart. Adapun flowchart media pembelajaran yang dikembangkan adalah sebagai berikut.

1) Zlengkap dengan, judul, nama kitab, halaman, juz, kota terbit, penerbit dan tahun terbitnya

2) Mendukung program Internet Sehat untuk "melawan" serbuan contentcontent yang kurang bermanfaat.

3) Menjadi sumber rujukan umat Islam yang terpercaya mengingat tidak sedikit website yang menampilkan informasi terkait Islam namun tidak ditulis oleh orang yang memiliki kompetensi.

Adapun keterbatasan pengguna dalam menggunakan aplikasi ini adalah sebagaimana ditunjukkan gambar 3.1. 


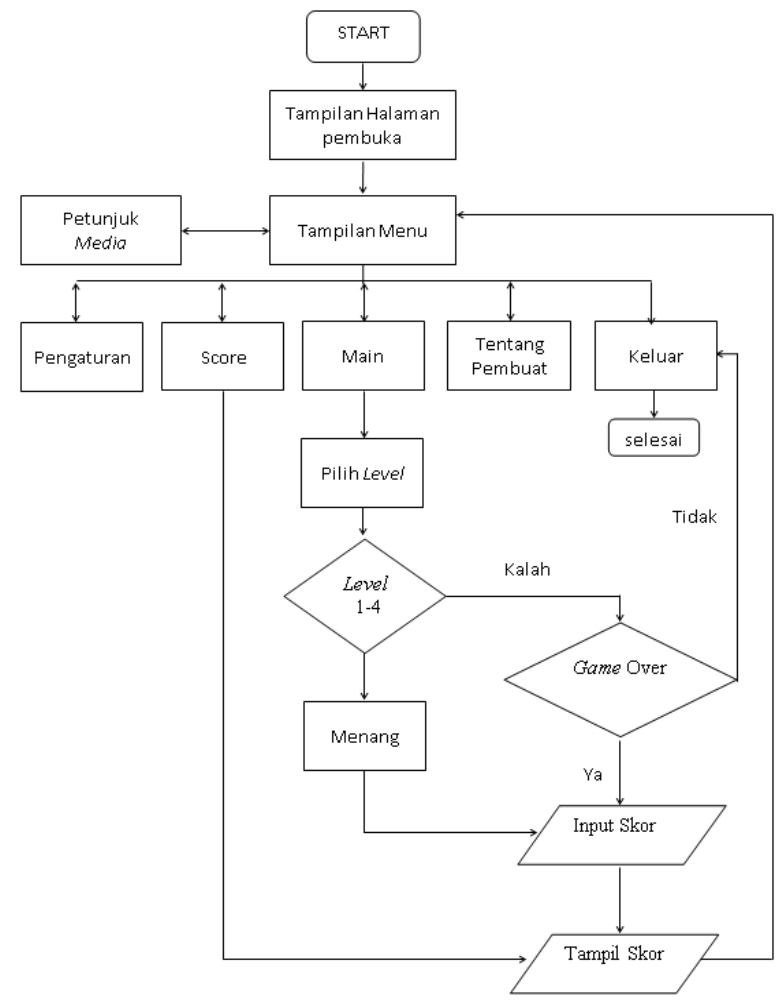

Gambar 3.1 Flowchart media pembelajaran matematika berbasis Android

Berdasarkan flowchart diatas dapat dijabarkan sebagai berikut: a) Ketika user membuka atau memulai start pada aplikasi android ini maka akan terbuka tampilan halaman pembuka media yang bertuliskan tentang nama media dan pembuat media, b) Tampilan selanjutnya adalah tampilan menu yang mana ditampilan menu ini akan didapati 6 buah tombol yaitu: main, pengaturan, score, tentang, keluar dan petunjuk, c) User bisa memilih level yang sudah terbuka pada menu pilih level. Untuk membuka kunci pada tampilan pilih level adalah dengan menyelesaikan level dasar dengan poin 100. Level 1 berisi simulasi materi dan permainan tentang bentukbentuk dan ciri-ciri bangun datar segi banyak dan bukan segi banyak, level 2 berisi simulasi materi dan permainan menghitung keliling persegipanjang, persegi, dan segitiga, level 3 berisi simulasi materi dan permainan menghitung luas daerah persegipanjang, persegi, dan segitiga, level 4 berisi simulasi materi dan permainan tentang hubungan antargaris, seperti garisgaris berpotongan, garis-garis sejajar, garisgaris berimpit. Adapun jenis permainan yang ditampilkan dalam media pembelajaran berbasis Android ini adalah puzzle, drag and drop, dan pilihan ganda.

Media pembelajaran berbasis aplikasi Android ini dikembangkan menggunakan Air For Android pada paket aplikasi Adobe Flash CS6 dengan Action Script 3.0. Pemilihan aplikasi ini didasarkan pada dua pertimbangan, yaitu: 1) aplikasi memiliki interface yang sederhana dalam membuat aplikasi Android, 2) Hasil studi pendahuluan peneliti menunjukkan bahwa beberapa guru SD/MI telah pernah mengikuti pelatihan pembuatan aplikasi Android menggunakan Adobe Air for Android pada aplikasi Adobe Flash (Prasetyo, 2017). 
c. Penilaian dan Revisi (develop)

Setelah rancangan produk berhasil dirancang berdasarkan flowchart dan storyboard yang direncanakan, peneliti melibatkan ahli materi matematika dan ahli media untuk menilai produk apakah secara rasional memiliki kelayakan untuk digunakan pada khalayak sasaran. Ahli materi Matematika dalam penelitian ini adalah Ibu Dessy Noor Ariani, M.Ed sebagai
Dosen Pembelajaran matematika pada Program Studi PGMI Universitas Islam Kalimantan MAB Banjarmasin yang memiliki keahlian di bidang pembelajaran matematika. Ahli materi banyak memberikan masukan terkait materi bangun datar. Adapun saran atau masukan dari ahli materi matematika adalah sebagaimana ditunjukkan tabel 3.1.

\section{Tabel 3.1 Saran atau Masukan dari Ahli Materi}

\begin{tabular}{cll}
\hline No. & \multicolumn{1}{c}{ Saran atau masukan } & Tindak lanjut \\
\hline 1. & Bahasa lebih lugas dan sesuai EYD & Sudah dilakukan \\
2. & Ukuran font diperbesar dan warnanya diperjelas & Sudah dilakukan \\
3. & Materi simulasi diperbanyak & Sudah dilakukan \\
4. & Kalimat petunjuk diperjelas & Sudah dilakukan \\
5. & Soal untuk evaluasi diperbanyak & Sudah dilakukan \\
\hline
\end{tabular}

Ahli media dalam penelitian ini adalah Bapak Zainal Abidin, M.Pd, Dosen yang ahli dibidang pembelajaran matematika Sekolah Dasar. Ahli media banyak memberi masukan terkait desain tampilan, tata letak, font, gambar, video, dan lain sebagainya. Adapun saran atau masukan dari ahli media adalah sebagaimana ditunjukkan tabel 3.2.

Tabel 3.2 Saran atau Masukan dari Ahli Media

\begin{tabular}{lll}
\hline No. & Saran atau masukan & Tindak lanjut \\
\hline 1. & Ukuran layar dicocokkan dengan ukuran layar smartphone & Sudah dilakukan \\
& pada umumnya & \\
2. & Tombol menu diperbesar dan jarak antar tombol & Sudah dilakukan \\
& direnggangkan & \\
3. & Penambahan penghitung waktu mundur pada permainan atau & Sudah dilakukan \\
& soal puzzle dan pilihan ganda
\end{tabular}



4. Volume suara latar diseragamkan
Sudah dilakukan
5. Warna tombol lanjut dikontraskan dengan latarnya
Sudah dilakukan

Setelah dinilai ahli, produk diperbaiki sesuai saran dan komentar para ahli. Hasil akhir revisi selanjutnya di export berupa aplikasi (.apk) yang bisa di install di smartphone untuk dinilai kualitasnya dan diujicobakan secara terbatas kepada siswa. Adapun contoh desain produk media pembelajaran matematika setelah dipasang di Smartphone adalah sebagaimana ditunjukkan gambar 3.2 berikut.
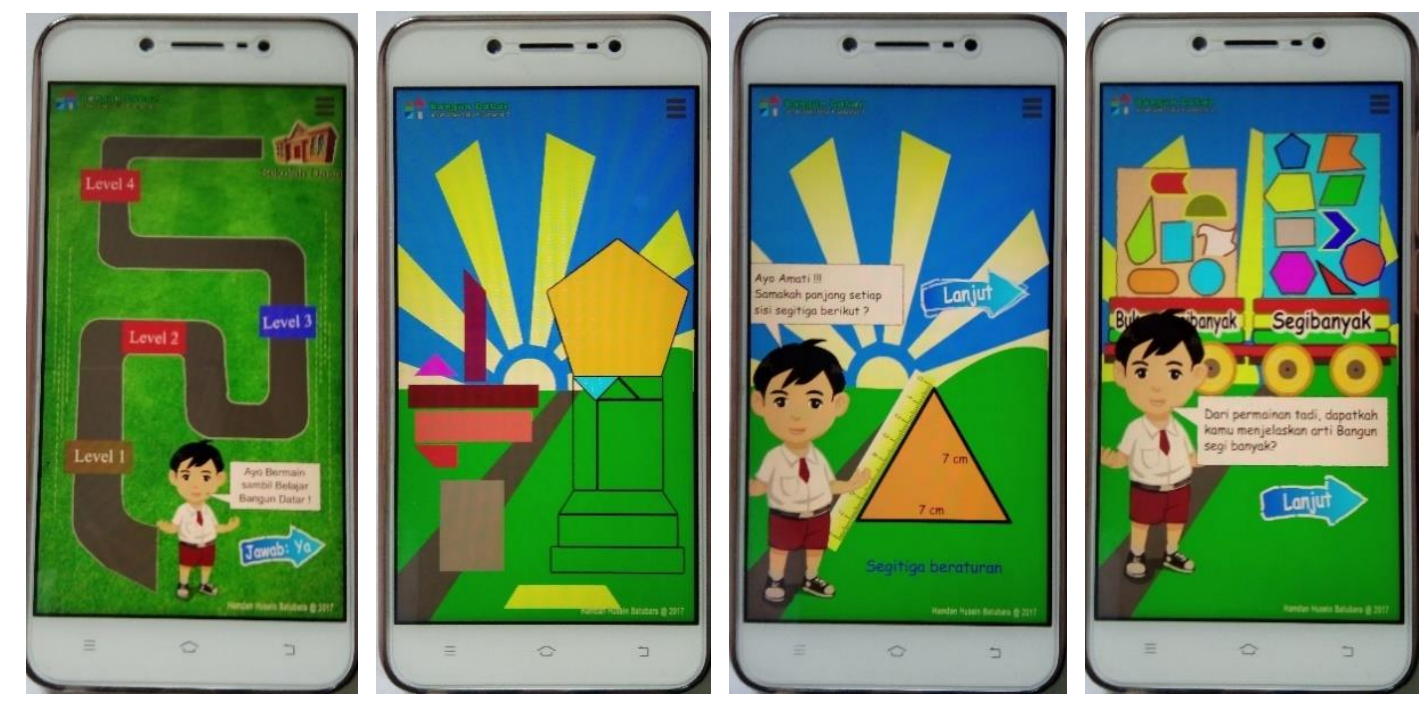

Gambar 3.2. Tampilan desain media pembelajaran matematika

Produk yang telah berbentuk Apk selanjutnya dinilai kualitasnya dengan melibatkan tiga orang peer reviewer (dosen) dan dua orang guru Madrasah Ibtidaiyah. Penilaian kualitas media pembelajaran berbasis android meliputi beberapa aspek, yaitu aspek struktur penyajian materi, aspek isi simulasi materi, aspek evaluasi belajar, aspek keterlaksanaan, aspek kualitas tampilan, aspek kebahasaan, dan aspek kejelasan kalimat. Hasil penilaian lima orang reviewer terhadap kualitas produk media pembelajaran berbasis android disajikan pada tabel 3.3 berikut. 
Tabel 3.3 Hasil Analisis Data Penilaian oleh Reviewer

\begin{tabular}{clcccc}
\hline No. & \multicolumn{1}{c}{ Aspek } & $\begin{array}{c}\text { Butir } \\
\text { Soal }\end{array}$ & $\begin{array}{c}\text { Total } \\
\text { Penilaian }\end{array}$ & $\begin{array}{c}\text { Rata-rata } \\
\text { per Aspek }\end{array}$ & $\begin{array}{c}\text { Persentase } \\
\text { penilaian per } \\
\text { Aspek }\end{array}$ \\
\hline 1 & Struktur penyajian materi & $1,2,3$ & 64 & 4,27 & $85,33 \%$ \\
2 & Isi simulasi materi & $4,5,6$ & 65 & 4,33 & $86,67 \%$ \\
3 & Evaluasi belajar & $7,8,9$ & 67 & 4,47 & $89,33 \%$ \\
4 & Keterlaksanaan & $10,11,12$ & 64 & 4,27 & $85,33 \%$ \\
5 & Kualitas tampilan & $13,14,15$ & 70 & 4,67 & $93,33 \%$ \\
6 & Kebahasaan & $16,17,18$ & 62 & 4,13 & $82,67 \%$ \\
7 & Kejelasan kalimat & 19,20 & 42 & 4,20 & $84,00 \%$ \\
\hline & & $\mathbf{2 0}$ & $\mathbf{4 3 4}$ & $\mathbf{4 , 3 3}$ & $\mathbf{8 6 , 6 7 \%}$ \\
\hline
\end{tabular}

Berdasarkan Tabel 3.3, penilaian keseluruhan yang dilakukan oleh reviewer menunjukkan bahwa kualitas produk media pembelajaran matematika berbasis android mempunyai kategori Sangat Baik (SB) dengan total penilaian $434(X>420)$, nilai rata-rata 4,33, dan persentase $86,67 \%$. Kategori sangat baik tersebut didasarkan pada hasil perhitungan kriteria ideal yang disajikan pada tabel 3.4 berikut.

Tabel 3.4 Perhitungan Kriteria Penilaian secara Keseluruhan Berdasarkan Rumus Kriteria Ideal

\begin{tabular}{cccc}
\hline No. & Rentang Skor Kuantitatif & Kategori & Rentang Skor \\
\hline 1 & $\mathrm{X}>\mathrm{Mi}+1,8 \mathrm{SBi}$ & Sangat baik (SB) & $\mathrm{X}>420$ \\
2 & $\mathrm{Mi}+0,6 \mathrm{SBi}<\mathrm{X} \leq \mathrm{Mi}+1,8 \mathrm{Sbi}$ & Baik (B) & $340<\mathrm{X} \leq 420$ \\
3 & $\mathrm{Mi}-0,6 \mathrm{SBi} \quad<\mathrm{X} \leq \mathrm{Mi}+0,6 \mathrm{Sbi}$ & Cukup (C) & $260<\mathrm{X} \leq 340$ \\
4 & $\mathrm{Mi}-1,8 \mathrm{SBi} \quad<X \leq \mathrm{Mi}-0,6 \mathrm{Sbi}$ & Kurang (K) & $180<X \leq 260$ \\
5 & $\mathrm{X} \leq \mathrm{Mi}-1,8 \mathrm{SBi}$ & Sangat kurang (SK) & $X \leq 180$ \\
\hline
\end{tabular}


Kualitas produk media pembelajaran berbasis android dilihat berdasarkan penilaian setiap aspek disajikan pada Tabel 3.5 berikut.

Tabel 3.5 Kualitas Produk Berdasarkan Penilaian pada Tiap-tiap Aspek

\begin{tabular}{clccc}
\hline No. & \multicolumn{1}{c}{ Aspek } & Kriteria & Rata-rata & Nilai \\
\hline 1 & Struktur penyajian materi & $1,2,3$ & 4,27 & Sangat baik \\
2 & Isi simulasi materi & $4,5,6$ & 4,33 & Sangat baik \\
3 & Evaluasi belajar & $7,8,9$ & 4,47 & Sangat baik \\
4 & Keterlaksanaan & $10,11,12$ & 4,27 & Sangat baik \\
5 & Kualitas tampilan & $13,14,15$ & 4,67 & Sangat baik \\
6 & Kebahasaan & $16,17,18$ & 4,13 & Baik \\
7 & Kejelasan Kalimat & 19,20 & 4,20 & Baik \\
\hline
\end{tabular}

Penilaian produk media pembelajaran berbasis android pada tiap-tiap aspek di atas didasarkan pada hasil perhitungan kriteria penilaian pada tabel 3.6 berikut.

Tabel 3.6 Perhitungan Kriteria Penilaian Tiap Aspek

\begin{tabular}{cccc}
\hline No. & Rentang Skor Kuantitatif & Kategori & Rentang Skor \\
\hline 1. & $\mathrm{X}>\mathrm{Mi}+1,8 \mathrm{Sbi}$ & Sangat baik (SB) & $\mathrm{X}>4,2$ \\
2. & $\mathrm{Mi}+0,6 \mathrm{SBi}<\mathrm{X} \leq \mathrm{Mi}+1,8 \mathrm{Sbi}$ & Baik (B) & $3,4<\mathrm{X} \leq 4,2$ \\
3. & $\mathrm{Mi}-0,6 \mathrm{SBi}<\mathrm{X} \leq \mathrm{Mi}+0,6 \mathrm{Sbi}$ & Cukup (C) & $2,6<\mathrm{X} \leq 3,4$ \\
4. & $\mathrm{Mi}-1,8 \mathrm{SBi}<X \leq \mathrm{Mi}-0,6 \mathrm{Sbi}$ & Kurang (K) & $1,8<X \leq 2,6$ \\
5. & $X \leq \mathrm{Mi}-1,8 \mathrm{Sbi}$ & Sangat kurang (SK) & $X \leq 1,8$ \\
\hline
\end{tabular}

Adapun indikator penilaian kualitas produk media pembelajaran berbasis android sesuai dengan pengelompokan aspek penilaiannya adalah sebagai berikut.

a. Struktur penyajian materi

Indikatornya meliputi: 1) Kesesuaian materi dengan buku kurikulum 2013 edisi revisi 2016, 2) teknik penyajian materi bangun datar, 3) organisasi materi bangun datar di kelas IV, 4) kelengkapan dan akurasi materi, 5) kesesuaian materi dengan perkembangan kognitif siswa, dan 6) penggunaan contoh yang ada di lingkungan sekitar.

b. Isi Simulasi Materi

Indikatornya meliputi: ketepatan 
simulasi materi dalam menggambarkan konsep, kejelasan simulasi materi, interaktifitas materi simulasi, kemenarikan materi simulasi, dan penggunaan contoh yang dekat diri siswa pada materi simulasi.

c. Evaluasi Belajar Indikatornya meliputi: petunjuk evaluasi mudah dipahami, soal sesuai dengan kompetensi dasar dan indikator pembelajaran, terdapat soal yang mengasah metode berpikir tingkat tingi dan mengarahkan siswa untuk menarik kesimpulan.

d. Keterlaksanaan

Indikatornya meliputi: penyajian materi mudah dipahami bagi siswa dan materi pokok sesuai dengan kurikulum terbaru.

e. Kualitas tampilan Indikatornya meliputi: desain program menarik, desain halaman teratur, font dan gambar jelas, gambar berhubungan dan mendukung kejelasan, dan animasi dapat menarik perhatian siswa untuk belajar.

f. Kebahasaan

Indikatornya meliputi: Pemilihan kata dalam penjabaran materi sangat baik, bahasa yang digunakan adalah Bahasa Indonesia yang baku dan menarik serta sesuai dengan EYD.

g. Kejelasan kalimat

Indikatornya meliputi: kalimat mudah dipahami, kebenaran dan ketepatan istilah matematika yang digunakan, dan kalimat yang digunakan tidak menimbulkan makna ganda.

Adapun beberapa saran dan masukan dari reviewer disajikan pada tabel 3.7 berikut.

Tabel 3.7. Saran dan masukan dari reviewer

\begin{tabular}{cll}
\hline No. & \multicolumn{1}{c}{ Saran atau masukan } & Tindak lanjut \\
\hline 1. & Materi simulasi diperbanyak & Sudah dilakukan \\
2. & Soal tantangan ditambah jumlah dan variasinya & Sudah dilakukan \\
3. & Tambahkan narasi suara pada bagian petunjuk & Sudah dilakukan \\
4. & Perlu diperkaya animasinya & Sudah dilakukan \\
5. & Penulisan kata disesuaikan dengan EYD & Sudah dilakukan \\
\hline
\end{tabular}




\section{Uji Coba Lapangan (disseminate)}

Uji coba lapangan dilakukan dengan mensosialisasikan aplikasi media pembelajaran kepada siswa lalu meminta siswa untuk memberikan komentar terhadap produk media pembelajaran berbasis android tersebut. Respon siswa terhadap produk media pembelajaran berbasis android meliputi beberapa aspek, yaitu aspek kemudahan pemahaman, aspek kemandirian belajar, aspek keaktifan dalam belajar, aspek minat terhadap media pembelajaran berbasis android, aspek penyajian media pembelajaran berbasis android, dan aspek penggunaan media pembelajaran berbasis Android.

Tanggapan siswa secara keseluruhan terhadap produk media pembelajaran berbasis android yang dilakukan oleh sepuluh orang siswa dapat dilihat pada tabel 3.8 berikut.

\section{Tabel 3.8 Tanggapan Siswa Terhadap Kualitas Produk}

\begin{tabular}{|c|c|c|c|c|c|}
\hline No. & Aspek & Kriteria & $\begin{array}{c}\text { Total } \\
\text { Penilaian }\end{array}$ & $\begin{array}{l}\text { Rata-rata } \\
\text { tiap aspek }\end{array}$ & $\begin{array}{l}\text { Persentase } \\
\text { penilaian } \\
\text { tiap aspek }\end{array}$ \\
\hline 1. & Kemudahan pemahaman & 1,2 & 85 & 4,25 & $85 \%$ \\
\hline 2. & Kemandirian belajar & 3,4 & 90 & 4,5 & $90 \%$ \\
\hline 3. & $\begin{array}{l}\text { Minat terhadap media } \\
\text { pembelajaran berbasis Android }\end{array}$ & 5,6 & 92 & 4,6 & $92 \%$ \\
\hline 4. & Kemanfaatan media & 7,8 & 85 & 4,25 & $85 \%$ \\
\hline 5. & $\begin{array}{l}\text { Kemudahan dalam } \\
\text { penggunaan }\end{array}$ & 9,10 & 87 & 4,35 & $87 \%$ \\
\hline & & & 439 & 4,39 & $87,8 \%$ \\
\hline
\end{tabular}

Total skor rata-rata dari penilaian siswa adalah 439. Dengan demikian, kualitas produk media pembelajaran berbasis android berdasarkan tanggapan sepuluh siswa adalah tergolong sangat baik (439 > 420). Nilai totalnya yang berjumlah 439 juga termasuk interval antara "Setuju (400) dan Sangat Setuju (500)" dengan persentasi $87,8 \%$.

Penilaian tersebut apabila dijabarkan sesuai dengan pengelompokan tiap-tiap aspeknya adalah sebagai berikut: 
a. Kemudahan pemahaman

Hal ini berarti siswa dapat mempelajari dan memahami karakteristik, keliling, dan luas bangun datar dengan mudah.

b. Kemandirian belajar

Hal ini berarti produk media pembelajaran berbasis android memberikan kesempatan belajar sesuai dengan kemampuan belajar siswa. Siswa secara mandiri dapat menggunakan media pembelajaran berbasis android pada materi pokok bangun datar sebagai media pembelajaran mandiri di luar sekolah.

c. Minat terhadap media pembelajaran berbasis android

Hal ini berarti bahwa siswa berminat belajar matematika menggunakan media pembelajaran berbasis android. Produk media pembelajaran berbasis android merupakan salah satu media pembelajaran matematika yang mengasyikkan dan dapat menambah minat siswa untuk belajar matematika.

d. Kemanfaatan media

Hal ini berarti media pembelajaran dapat membantu siswa dalam memahami konsep materi pelajaran matematika dengan cara yang seru dan asyik.

e. Kemudahan dalam penggunaan

Hal ini berarti media pembelajaran berbasis android mudah digunakan secara mandiri di luar kelas dan di luar jam mata pelajaran.

Saran atau masukan dari siswa untuk produk media pembelajaran berbasis android adalah sebagaimana ditunjukkan Tabel 9 berikut.

Tabel 9. Saran dan Masukan dari Siswa

\begin{tabular}{clc}
\hline No. & Saran atau Masukan & Tindak lanjut \\
\hline 1. & Soalnya kurang banyak & Sudah dilakukan \\
2. & Font kurang besar & Sudah dilakukan \\
3. & Gambarnya kurang & Sudah dilakukan \\
\hline
\end{tabular}

\section{PENUTUP}

Setelah melakukan pengkajian teori dan hasil penelitian maupun pembahasan, maka dapat ditarik suatu simpulan sebagai berikut: 1) telah dihasilkan sebuah produk media pembelajaran matematika berbasis android materi pada bangun datar untuk siswa kelas IV SD/MI, meliputi karakteristik proses (analisis, desain produk, pengembangan dan validasi desain, revisi 
desain, dan uji coba produk) dan karakteristik produk (judul, pendahuluan, pilihan level, simulasi materi, dan permainan), 2) media pembelajaran matematika berbasis android memperoleh penilaian dari reviewer, peer reviewer, dan guru SD/MI dengan skor 434 dan persentase $86,67 \%$ yang berarti sangat baik, 3) respon atau tanggapan siswa kelas IV SD/ MI terhadap media pembelajaran matematika berbasis android memperoleh skor 439 dengan persentase penilaian $87,8 \%$. Nilai tersebut berada pada interval antara "Setuju dan Sangat Setuju". Dengan demikian sesuai batas-batas hasil review dan tanggapan siswa, produk media pembelajaran berbasis android dalam penelitian ini dapat digunakan oleh siswa SD/MI.

\section{RUJUKAN}

[1] Batubara, H. H. (2015). Pengembangan Media Pembelajaran Interaktif pada Materi Operasi Bilangan Bulat. MUALLIMUNA: Jurnal Madrasah Ibtidaiyah, 1(1), 1-12.

[2] Lidinillah, D. A. M. (2008). Strategi Pembelajaran Pemecahan Masalah di Sekolah Dasar. Jurnal Pendidikan Dasar, 110.

[3] Menteri Pendidikan Nasional RI. Peraturan Menteri Pendidikan Nasional Nomor 16 Tahun 2007 Tanggal 4 Mei
2007 Tentang Standar Kualifikasi Akademik Dan Kompetensi Guru, BSNP $\S(2007)$.

[4] Mulyatiningsih, E. (2014). Metode Penelitian Terapan Bidang Pendidikan. Bandung: Alfabeta.

[5] Nur'aeni, E. (2010). Pengembangan Kemampuan Komunikasi Geometris Siswa Sekolah Dasar Melalui Pembelajaran berbasis Teori Van Hiele.

[6] Prasetyo, S. (2017). Pengembangan Media Pembelajaran IPA berbasis Android Untuk Siswa SD/MI, 1(1), 122141.

[7] Sembiring, S. \& G. A. (2017). Ayo Belajar Menalar Matematika untuk Siswa SD/MI Kelas IV. (D. Kurniawati, Ed.) (III). Bandung: Penerbit Yrama Widya.

[8] UNESCO. (2011). UNESCO ICT Competency Framework for Teacher. UNESCO and Microsoft. France: UNESCO and Microsoft. https://doi.org/10.1017/CBO97811074153 24.004

[9] Waskito, D. (2014). Media Pembelajaran Interaktif Matematika Bagi Sekolah Dasar Kelas 6 Berbasis Multimedia. Speed Journal - Sentra Penelitian Engineering Dan Edukasi, 11(3), 59-65. 